\title{
APLIKASI PEMBELAJARAN BAHASA SUNDA DENGAN IMPLEMENTASI ALGORITMA LINEAR CONGRUENTIAL GENERATOR DAN FUZZY BERBASIS ANDROID
}

\author{
Ganteng Eki Pribadi ${ }^{1}$, Undang Syaripudin ${ }^{2}$, Wisnu Uriawan ${ }^{3}$ \\ 1,2,3 Jurusan Teknik Informatika, Fakultas Sains dan Teknologi \\ Universitas Islam Negeri Sunan Gunung Djati Bandung \\ Jl. A.H. Nasution 105, Bandung 40614 Indonesia \\ ${ }^{1}$ gantengekip@gmail.com, ${ }^{2}$ undang.syaripudin@uinsgd.ac.id, ${ }^{3}$ wisnu_u@ @ruinsgd.ac.id
}

\begin{abstract}
Abstrak- Bahasa merupakan media komunikasi yang penting bagi manusia. Salah satunya bahasa Sunda yang merupakan salah satu bahasa Ibu untuk sebagian orang di Indonesia khususnya daerah Jawa Barat dan Banten. Seiring perkembangan zaman hanya $40 \%$ anak di daerah Jawa Barat dan sekitarnya yang mampu dan paham berbahasa Sunda, jika dibiarkan terus terjadi maka Suku Sunda akan kehilangan identitasnya. Seiring dengan perkembangan zaman android merupakan kebutuhan bagi manusia, karena hal tersebut android bisa dijadikan media pembelajaran. Dengan bantuan media android untuk pembelajaran bahasa Sunda diharapkan dapat membantu anak-anak meningkatkan hafalan kosakata bahasa Sunda. Penilaian menjadi tolak ukur keberhasilan pembelajaran, metode Fuzzy dapat membantu penilaian di dalam sistem pembelajaran ini serta algoritma Linear Congruential Generator dapat membantu dalam proses pengacakan soal yang ada pada sistem pembelajaran ini.
\end{abstract}

Kata Kunci: Bahasa Sunda, Linear Congruential Generator, Fuzzy, Aplikasi Andoird.

\section{PENDAHULUAN}

Bahasa merupakan salah satu alat komunikasi yang sangat penting bagi manusia. Dengan bahasa kita bisa mengungkapkan segala hal yang kita pikirkan. Dengan bahasa pula nenek moyang menurunkan kebudayaannya kepada anak cucunya. Bahkan pendidikan dan segala macam disiplin ilmu dapat tersampaikan dengan efektif melalui bahasa, salah satunya yaitu bahasa Sunda.

Bahasa Sunda adalah sebuah bahasa dari cabang Melayu-Polinesia dalam rumpun bahasa Austronesia [1]. Bahasa ini dituturkan oleh setidaknya 38 juta orang dan merupakan bahasa Ibu dengan penutur terbanyak kedua di Indonesia setelah bahasa Jawa. Bahasa Sunda dituturkan dihampir seluruh provinsi Jawa Barat dan Banten, serta wilayah barat Jawa Tengah mulai dari Kali Brebes (Sungai Cipamali) di wilayah Kabupaten Brebes dan Kali Serayu (Sungai Ciserayu) di Kabupaten Cilacap, di sebagian kawasan Jakarta, serta di seluruh provinsi di Indonesia dan luar negeri yang menjadi daerah urbanisasi Suku Sunda.

Seiring dengan perkembangan zaman, masyarakat sering mengabaikan bahasa ibu atau daerah masing-masing, termasuk bahasa Sunda. Hanya sekitar 40\% anak Jawa Barat yang mengetahui dan mampu berbahasa Sunda [2]. Sehingga jika hal ini dibiarkan terus terjadi, Suku Sunda akan kehilangan identitas budaya daearahnya.

Kosakata memegang peran penting dalam kehidupan sehari-hari, karena ide dan pikiran seseorang hanya akan dipahami dengan baik oleh pihak lain apabila ide tersebut dapat diungkapkan dengan kosakata yang dipilih secara tepat. Menurut Kamus Umum Bahasa Indonesia [3], kosakata berarti perbendaharaan kata-kata, dan perbendaharaan, berarti pemahaman serta keterampilan. Sehingga perbendaharaan kosakata bahasa Sunda dapat diartikan sebagai pemahaman serta keterampilan mengenai perbendaharaan katakata bahasa Sunda.

Belajar bahasa Sunda tidak akan terlepas dari belajar kosakata, penguasaan kosakata merupakan hal terpenting dalam keterampilan berbahasa Sunda. Tanpa penguasaan kosakata yang memadai maka keterampilan berbahasa anak sulit dicapai dan pemahaman anak mengenai kosakata bahasa Sunda tidak akan berkembang. Untuk itu kosakata merupakan dasar pembelajaran bahasa Sunda.

Dari pendapat tersebut diungkapkan bahwa kosakata merupakan aspek dasar yang sangat penting untuk mempelajari bahasa Sunda dan terdapat hubungan erat antara belajar bahasa dengan belajar kosakata. Sebuah pertanyaan yang sederhana bagaimana orang-orang dapat mengenal juga belajar tentang kosakata dimulai dari yang biasa terlihat sehari-hari dan melihat perkembangan zaman sekarang ini perangkat smartphone android 
merupakan salah satu media yang dapat dijadikan sebagai pembelajaran.

Fungsi dan peran perangkat smartphone android tidak dapat dipungkiri sangat membantu dalam media pembelajaran. Cara ini sangatlah tepat mengingat pengguna smartphone android sudah beranjak tidak hanya untuk orang dewasa tapi bahkan anak kecil sudah banyak menggunakannya. Tercatat pada gs.statcounter.com pengguna smartphone android di Indonesia pada tahun 2015 mencapai $68.75 \%$ [4].

Fungsi pengacakan merupakan sebuah fungsi yang biasanya dilakukan untuk mengacak sebuah urutan. Terdapat berbagai macam algoritma pengacakan untuk memberikan teknik pengacakan angka. Salah satunnya yaitu algoritma Linear Congruential Generator. Algoritma ini merupakan salah satu jenis pembangkit bilangan acak semu. Keunggulan algoritma ini terletak pada kecepatannya dan hanya membutuhkan sedikit operasi bit.

Logika Fuzzy merupakan logika yang berhadapan langsung dengan konsep kebenaran sebagian, di mana logika klasik menyatakan bahwa segala hal dapat diekspresikan dalam biner 0 atau 1 . Logika Fuzzy memungkinkan nilai keanggotaan antara 0 dan 1. Logika Fuzzy menyediakan cara sederhana untuk menggambarkan kesimpulan pasti dari informasi yang ambigu, samar-samar, atau tidak tepat. Sedikit banyak, logika Fuzzy menyerupai keputusasn pada manusia dengan kemampuannya untuk bekerja dari data yang ditafsirkan dan mencari solusi yang tepat. Ada beberapa metode Fuzzy diantaranya yaitu metode Tsukamoto. Metode Tsukamoto memiliki kelebihan yaitu lebih intuitif, diterima oleh banyak pihak, lebih cocok untuk masukan yang diterima dari manusia bukan mesin [5].

\section{LANDASAN TEORI}

A. Bahasa Sunda

Bahasa Sunda adalah sebuah bahasa dari cabang Melayu-Polinesia dalam rumpun bahasa Austronesia [1]. Bahasa ini dituturkan oleh setidaknya 38 juta orang dan merupakan bahasa Ibu dengan penutur terbanyak kedua di Indonesia setelah Bahasa Jawa. Bahasa Sunda dituturkan dihampir seluruh provinsi Jawa Barat dan Banten, serta wilayah barat Jawa Tengah mulai dari Kali Brebes (Sungai Cipamali) di wilayah Kabupaten Brebes dan Kali Serayu (Sungai Ciserayu) di Kabupaten Cilacap, disebagian kawasan Jakarta, serta diseluruh provinsi di Indonesia dan luar negeri yang menjadi daerah urbanisasi Suku Sunda.

Setidaknya sejak Abad IV masyarakat Sunda telah lama mengenal aksara untuk menulis bahasa yang mereka gunakan. Namun demikian pada awal masa kolonial, masyarakat Sunda dipaksa oleh penguasa dan keadaan untuk meninggalkan penggunaan Aksara Sunda Kuna yang merupakan salah satu identitas budaya Sunda. Keadaan yang berlangsung hingga masa kemerdekaan ini menyebabkan punahnya Aksara Sunda Kuna dalam tradisi tulis masyarakat Sunda.

Pada akhir Abad XIX sampai pertengahan Abad XX, para peneliti berkebangsaan asing (misalnya K. F. Holle dan C. M. Pleyte) dan bumiputra (misalnya Atja dan E. S. Ekadjati) mulai meneliti keberadaan prasasti-prasasti dan naskah-naskah tua yang menggunakan Aksara Sunda Kuna. Berdasarkan atas penelitianpenelitian sebelumnya, pada akhir Abad XX mulai timbul kesadaran akan adanya sebuah Aksara Sunda yang merupakan identitas khas masyarakat Sunda. Oleh karena itu Pemerintah Daerah Provinsi Jawa Barat menetapkan Perda No. 6 tahun 1996 tentang Pelestarian, Pembinaan dan Pengembangan Bahasa, Sastra dan Aksara Sunda yang kelak digantikan oleh Perda No. 5 tahun 2003 tentang Pemeliharaan Bahasa, Sastra, dan Aksara Daerah.

Pada tanggal 21 Oktober 1997 diadakan Lokakarya Aksara Sunda di Kampus UNPAD Jatinangor yang diselenggarakan atas kerja sama Pemerintah Daerah Tingkat I Jawa Barat dengan Fakultas Sastra Universitas Padjajaran. Kemudian hasil rumusan lokakarya tersebut dikaji oleh Tim Pengkaji Aksara Sunda. Dan akhirnya pada tanggal 16 Juni 1999 keluar Surat Keputusan Gubernur Kepala Daerah Tingkat I Jawa Barat Nomor 343/SK.614-Dis.PK/99 yang menetapkan bahwa hasil lokakarya serta pengkajian tim tersebut diputuskan sebagai Aksara Sunda Baku.

Berikut adalah Aksara Sunda baku:

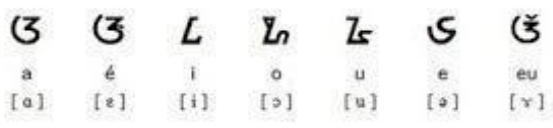

Gambar 2.1. Aksara Sunda Vokal [9] 


\section{Z Z \\ 诮 \\ 2N 7 . 77 . 7 \\ U.}

$\pi \cap 7 \mathrm{~m}$

Gambar 2.2. Aksara Sunda Konsonan [9]

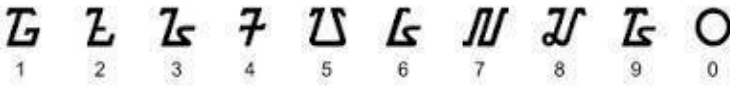

Gambar 2.3. Aksara Sunda Angka [9]

\section{B. Linear Congruential Generator (LCG)}

Linear Congruential Generator merupakan salah satu jenis bilangan acak semu. LCG menggunakan metode linier dalam membangkitkan bilangan acak dalam jumlah besar dan waktu yang cepat [11]. Model matematis LCG dapat dihitung dengan menggunakan persamaan [11]:

Keterangan:

$\mathrm{Xn}+1=$ bilangan acak ke- $\mathrm{n}$ dari deretnya

$\mathrm{Xn}=$ bilangan acak sebelumnya

$\mathrm{a}=$ faktor pengali

$\mathrm{b}=$ penambah

$\mathrm{n}=0,1,2,3, \ldots$ dan seterusnya

LCG memiliki periode penuh jika dan hanya jika [11]:

1) b relatif prima terhadap $m$.

2) a-1 dapat dibagi dengan setiap factor prima dari $m$.

3) a-1 adalah kelipatan 4 jika $m$ adalah kelipatan 4.

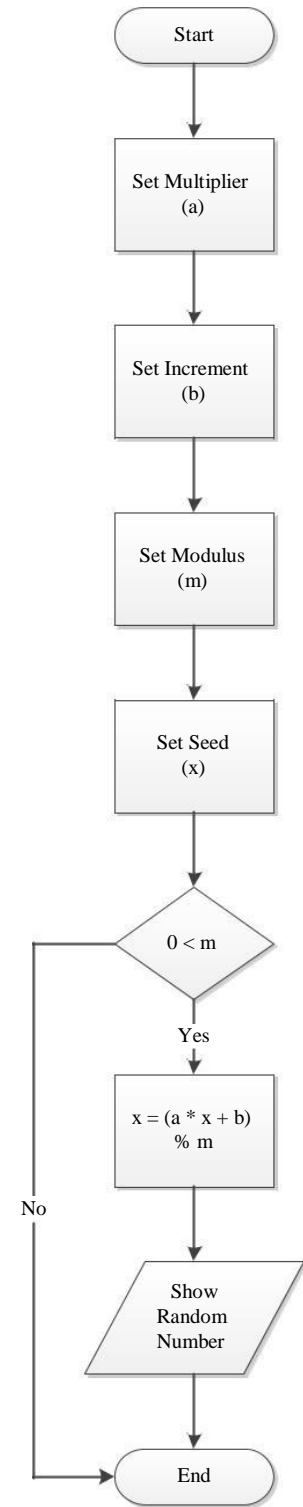

Gambar 2.4. Flowchart Algoritma LCG

C. Fuzzy

Konsep tentang logika fuzzy diperkenalkan oleh Prof. Lotfi Astor Zadeh pada 1962. Logika fuzzy adalah metodologi sistem kontrol pemecahan masalah, yang cocok untuk diimplementasikan pada sistem, mulai dari sistem yang sederhana, sistem kecil, embedded system, jaringan PC, multi-channel atau workstation berbasis akuisisi data, dan sistem kontrol. Metodologi ini dapat diterapkan pada perangkat keras, perangkat lunak, atau kombinasi keduanya. Dalam logika klasik dinyatakan bahwa segala sesuatu bersifat biner, yang artinya adalah hanya mempunyai dua kemungkinan, "Ya atau Tidak", "Benar atau Salah", "Baik atau Buruk", dan lain-lain. Oleh karena itu, semua ini dapat mempunyai nilai 
keanggotaan 0 atau 1. Akan tetapi, dalam logika fuzzy memungkinkan nilai keanggotaan berada diantara 0 dan 1. Artinya, bisa saja suatu keadaan mempunyai dua nilai "Ya dan Tidak", "Benar dan Salah", "Baik dan Buruk" secara bersamaan, namun besar nilainya tergantung pada bobot keanggotaan yang dimilikinya. Logika fuzzy dapat digunakan diberbagai bidang, seperti pada sistem diagnosis penyakit (dalam bidang kedokteran); pemodelan sistem pemasaran, riset operasi (dalam bidang ekonomi); kendali kualitas air, prediksi adanya gempa bumi, klasifikasi dan pencocokan pola (dalam bidang teknik).

\section{1) Dari Himpunan Klasik ke Himpunan Samar (Fuzzy)}

Misalkan U sebagai semesta pembicara (himpunan semesta) yang berisi semua anggota yang mungkin dalam setiap pembicaraan atau aplikasi. Misalkan himpunan tegas A dalam semesta pembicaraan U. Dalam matematika ada tiga metode atau bentuk untuk menyatakan himpunan, yaitu metode pencacahan, metode pencirian dan metode keanggotaan. Metode pencacahan digunakan apabila suatu himpunan didefinisikan dengan mencacah atau mendaftar anggota-anggotanya. Sedangkan metode pencirian, digunakan apabila suatu himpunan didefinisikan dengan menyatakan sifat anggotaanggotanya [5]. Dalam kenyataannya, cara pencirian lebih umum digunakan, kemudian setiap himpunan A ditampilkan dengan cara pencirian sebagai berikut:

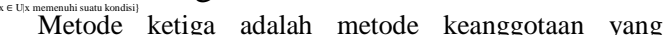
mempergunakan fungsi keanggotaan nol-satu untuk setiap himpunan A yang dinyatakan sebagai $\mu \mathrm{A}(\mathrm{x})$

Dengan kata lain jika A adalah himpunan tegas, maka nilai keanggotaanya hanya terdiri dari dua nilai yaitu 0 dan 1. Sedangkan nilai keanggotaan di dimpunan fuzzy adalah interval tertutup $[0,1]$.

2) Atribut

Himpunan fuzzy memiliki 2 atribut [5], yaitu:

a) Linguistik, yaitu penamaan suatu grup yang mewakili suatu keadaan atau kondisi tertentu dengan menggunakan bahasa alami, seperti: Muda, Parobaya, Tua.

b) Numeris, yaitu suatu nilai (angka) yang menunjukan ukuran dari suatu variabel seperti: 40, 25, 50, dsb.

\section{3) Istilah-istilah Dalam Logika Fuzzy}

Ada beberapa istilah yang perlu diketahui dalam memahami sistem fuzzy, yaitu:

a) Variabel Fuzzy

Variabel fuzzy merupakan variabel yang hendak dibahas dalam suatu sistem fuzzy [5]. Contoh: Umur, Temperatur, Permintaan, Persediaan, Produksi dan sebagainya.

b) Himpunan Fuzzy

Misalkan X semesta pembicaraan, terdapat $\mathrm{A}$ di dalam $\mathrm{X}$ sedemikian sehingga:

Suatu himpunan fuzzy A di dalam semesta pembicaraan $\mathrm{X}$ didefinisikan sebagai himpunan yang bercirikan suatu fungsi keanggotaan, yang mengawankan setiap dengan bilangan real di dalam interval, dengan nilai menyatakan derajat keanggotaan $\mathrm{x}$ di dalam A [5]. Himpunan fuzzy merupakan suatu grup yang mewakili suatu kondisi atau keadaan tertentu dalam suatu variabel fuzzy. Misalkan $\mathrm{X}=$ Umur adalah variabel fuzzy. Maka dapat didefinisikan himpunan "Muda", "Parobaya", dan "Tua" [5].

c) Semesta Pembicaraan

Semesta pembicaraan adalah keseluruhan nilai yang diperbolehkan untuk dioperasikan dalam suatu variabel fuzzy. Semesta pembicaraan merupakan himpunan bilangan real yang senantiasa naik (bertambah) secara monoton dari kiri ke kanan. Nilai semesta pembicaraan dapat berupa bilangan positif maupun negatif. Adakalanya nilai semesta pembicaraan ini tidak dibatasi batas atasnya. Contoh: semesta pembicaraan untuk variabel umur: [5]. Sehingga semesta pembicaraan dari variabel umur adalah

diperbolehkan untuk dioperasikan dalam variabel umur adalah lebih besar dari 
atau sama dengan 0 , atau kurang dari positif tak hingga.

d) Domain

Domain himpunan fuzzy adalah keseluruhan nilai yang diijinkan dalam semesta pembicaraan dan boleh dioperasikan dalam suatu himpunan fuzzy. Seperti halnya semesta pembicaraan, domain merupakan himpunan bilangan real yang senantiasa naik (bertambah) secara monoton dari kiri ke kanan. Nilai domain dapat berupa bilangan positif maupun negatif. Contoh domain himpunan fuzzy: Muda $=[0,45]$ [5].

\section{4) Fungsi Keanggotaan}

Bentuk ini paling sederhana dan menjadi pilihan yang baik untuk mendekati suatu konsep yang kurang jelas. Ada 2 keadaan himpunan fuzzy yang linear, yaitu representasi linear naik dan representasi linear turun.

a) Representasi Linear NAIK

Fungsi keanggotaan representasi linear naik dapat dicari dengan cara sebagai berikut:$$
\mu[x]=1
$$

Himpunan fuzzy pada representasi linear NAIK direpresentasikan pada Gambar 2.5.

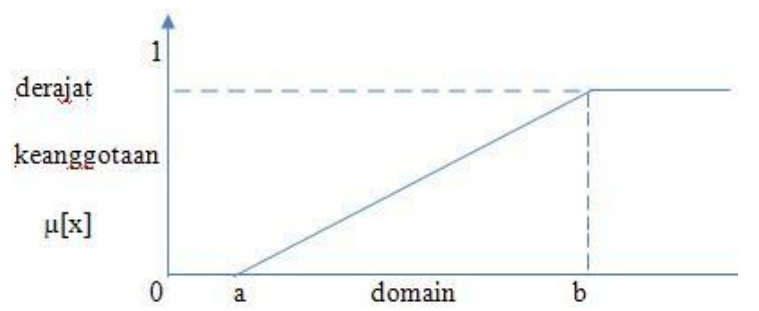

Gambar 2.5. Grafik Representasi Linear Naik [5]

b) Representasi Linear TURUN

Fungsi keanggotaan representasi linear TURUN dapat dicari dengan cara sebagai berikut:

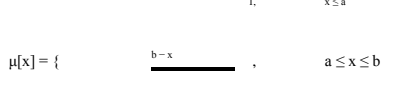

Himpunan fuzzy pada representasi linear turun direpresentasikan pada Gambar 2.6 .

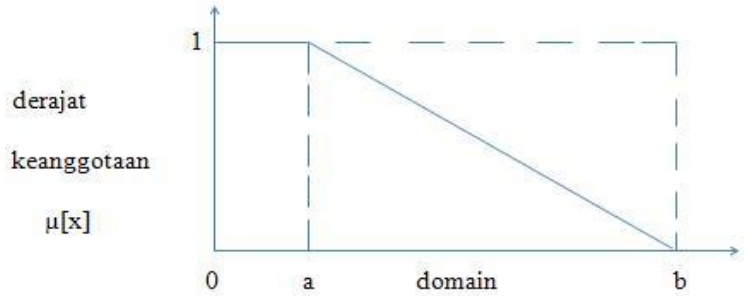

Gambar 2.6. Grafik Representasi Linear Turun [5]

\section{5) Teori Operasi Himpunan}

Menurut Lin dan Lee [5], ada dua operasi pokok dalam himpunan fuzzy, yaitu:
a. Konjungsi Fuzzy
Konjungsi fuzzy dari $\mathrm{A}$ dan $\mathrm{B}$ dilambangkan dengan $\mathrm{A} \Delta \mathrm{B}$ dan didefinisikan oleh:
b. Disjungsi Fuzzy
Disjungsi fuzzy dari A dan B dilambangkan dengan ADB dan didefinisikan oleh:

6) Metode Fuzzy Inference System (FIS) Tsukamoto

Inferensi adalah proses penggabungan banyak aturan berdasarkan data yang tersedia. Komponen yang melakukan inferensi dalam sistem pakar disebut mesin inferensi. Dua pendekatan untuk menarik kesimpulan pada IF-THEN rule (aturan jikamaka) adalah forward chaining dan backward chaining [5].

Metode defuzifikasi yang digunakan dalam metode Tsukamoto adalah metode defuzifikasi rata-rata terpusat (Center Average Defuzzyfier).

\section{PERANCANGAN}

\section{A. Use Case Diagram}

Use case diagram menggambarkan fungsionalitas yang diharapkan dari sebuah sistem. Sebuah use case mempresentasikan sebuah interaksi antara aktor dengan sistem. Gambar 3.1 merupakan perancangan use case diagram yang diusulkan. 


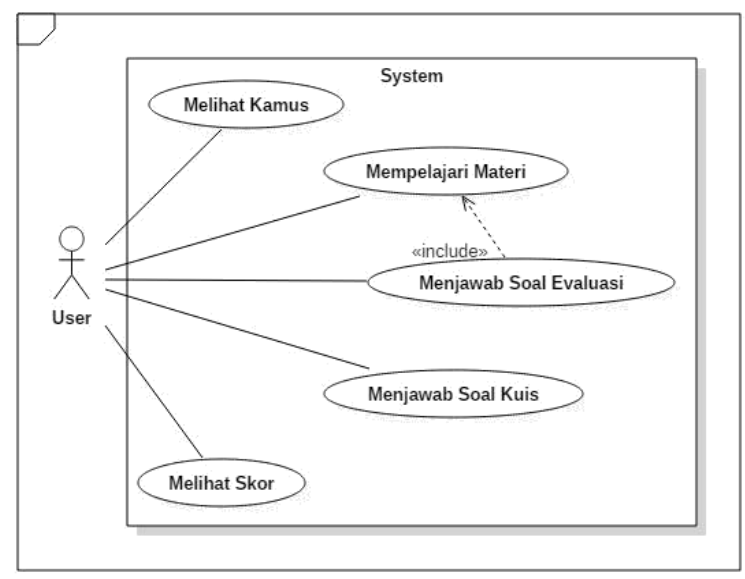

Gambar 3.1. Use Case Diagram

\section{B. Class Diagram}

Diagram ini memperlihatkan himpunan kelas-kelas, antarmuka-antarmuka, kolaborasikolaborasi dan relasi-relasi. Diagram ini umum ditemui pada pemodelan berorientasi objek. Meski sifatnya statis, sering pula memuat kelaskelas aktif. Berikut ini merupakan class diagram aplikasi pembelajaran bahasa Sunda.

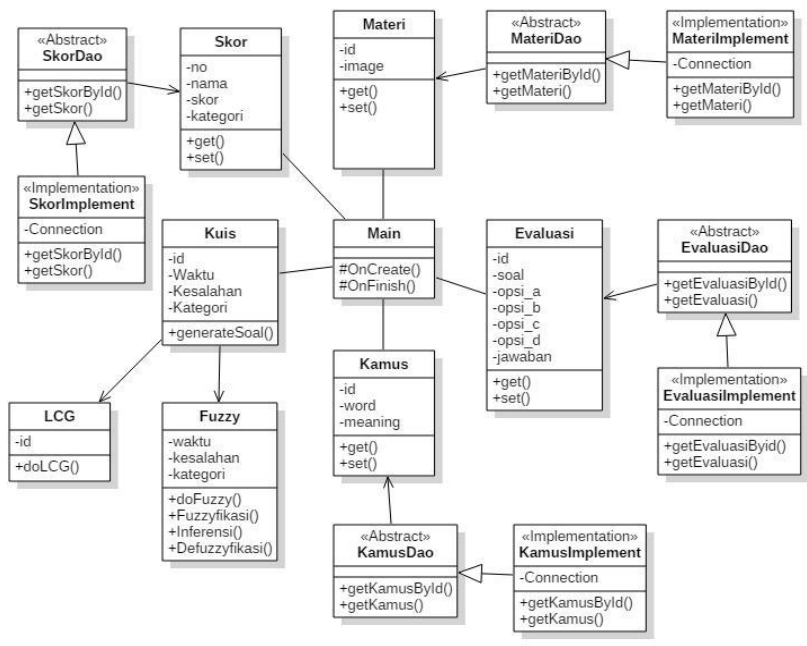

Gambar 3.2. Class Diagram

\section{IMPLEMENTASI}

\section{A. Implementasi Antarmuka}

1) Tampilan Halaman Utama

Gambar 4.1 halaman menu utama, terdiri dari beberapa menu yaitu, materi, kamus, kuis, skor, dan keluar.

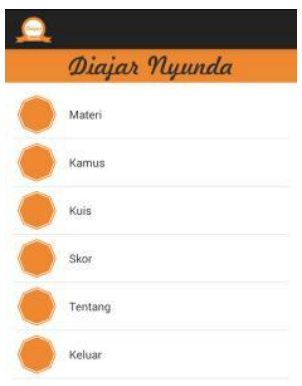

\section{Gambar 4.1. Halaman Utama}

2) Tampilan Halaman Daftar Materi

Gambar 4.2 halaman daftar materi, terdapat lima materi yaitu huruf Sunda, angka Sunda, istilah keluarga, warna, dan panca indra.

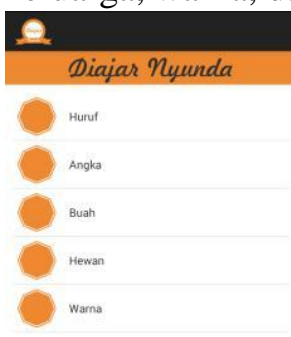

\section{Gambar 4.2. Halaman Daftar Materi}

3) Tampilan Halaman Materi

Gambar 4.3 halaman materi, menyajikan materi yang telah dipilih dari menu sebelumnya pada halaman daftar materi.

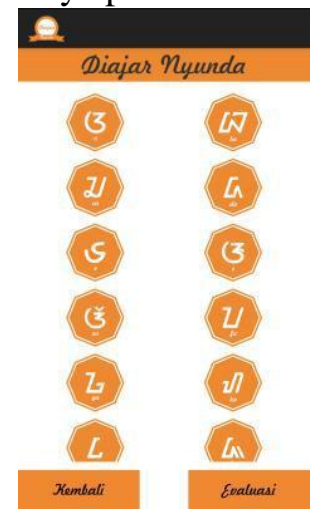

Gambar 4.3. Halaman Materi

4) Tampilan Halaman Pembelajaran

Gambar 4.4 halaman evaluasi, menyajikan soal latihan dari pembelajran sebelumnya. 


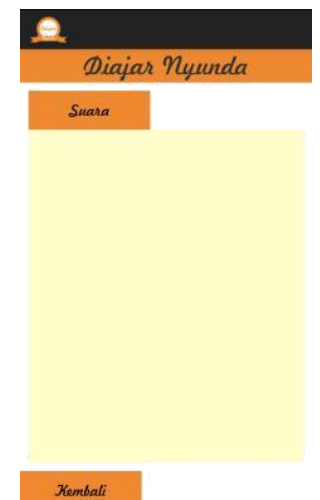

Gambar 4.4. Halaman Pembelajaran

5) Tampilan Halaman Evaluasi Gambar 4.5 halaman pembelajaran, pada halaman ini user dapat belajar cara penulisan aksara Sunda.

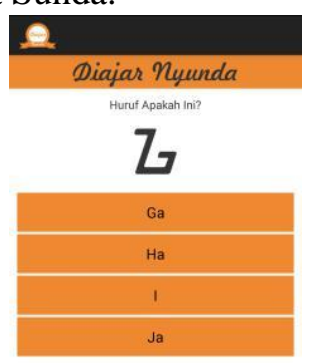

\section{Gambar 4.5. Halaman Evaluasi}

6) Tampilan Halaman Kamus

Gambar 4.6 halaman kamus, dapat menerjemahkan kata Indonesia-Sunda atau sebaliknya Sunda-indonesia.

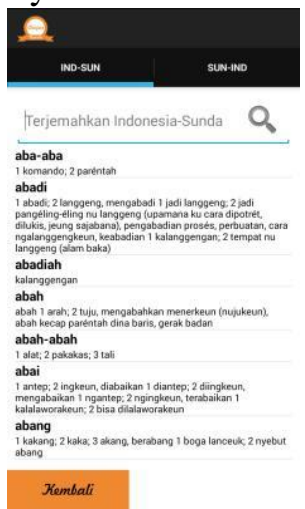

\section{Gambar 4.6. Halaman Kamus}

7) Tampilan Halaman Kuis

Gambar 4.7 halaman kuis. Salah satu fitur dari aplikasi ini yaitu halaman kuis, terdapat sebuah pertanyaan berupa gambar dan kemudian user menjawabnya dengan cara drag and drop jawabannya ke dalam kotak jawaban yang telah disediakan.
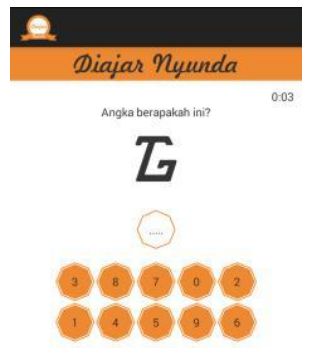

\section{Gambar 4.7. Halaman Kuis}

8) Tampilan Halaman Skor

Gambar 4.8 halaman skor, pada halaman ini user dapat melihat skor setelah user berhasil menjawab soal dari menu kuis.

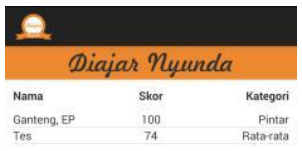

Gambar 4.8. Halaman Skor

B. Pengujian Algoritma

1) Algoritma Linear Congruential Generator

Tabel 4.1. Hasil Pengujian LCG

\begin{tabular}{|l|l|l|l|l|c|}
\hline \multirow{2}{*}{ No } & \multicolumn{4}{|c|}{ Input } & \multirow{2}{*}{ Output } \\
\cline { 2 - 5 } & $\mathbf{x 0}$ & $\mathbf{a}$ & $\mathbf{b}$ & $\mathbf{m}$ & \\
\hline 1 & 0 & 1 & 1 & 10 & 1234567890 \\
\hline 2 & 1 & 1 & 1 & 10 & 2345678901 \\
\hline 3 & 2 & 1 & 1 & 10 & 3456789012 \\
\hline 4 & 3 & 1 & 1 & 10 & 4567890123 \\
\hline 5 & 4 & 1 & 1 & 10 & 5678901234 \\
\hline 6 & 5 & 1 & 1 & 10 & 6789012345 \\
\hline 7 & 6 & 1 & 1 & 10 & 7890123456 \\
\hline 8 & 7 & 1 & 1 & 10 & 8901234567 \\
\hline 9 & 8 & 1 & 1 & 10 & 9012345678 \\
\hline 10 & 9 & 1 & 1 & 10 & 0123456789 \\
\hline
\end{tabular}


Dari hasil Tabel 4.1 dapat dilihat bahwa output yang dihasilkan berbeda, hal ini dikarenakan nilai pembangkit awal (x0) berbeda, itu menunjukan bahwa algoritma Linear Congruential Generator dalam hal proses pengacakanya tergantung pada variabelvariabel seperti x0 (bilangan pembangkit awal), a (faktor penggali), b (penambah) dan m (modulus).

2) Metode Fuzzy

Validasi sistem ini akan dicari tingkat validitas sistem dengan menggunakan 5 jenis data, yang salah satunya menggunakan Contoh 3.2 serta 4 jenis data lain (langkah-langkah perhitungannya tidak disajikan). Hasil perhitungan tersebut disajikan pada Tabel 4.2.

Tabel 4.2. Hasil Uji Validitas Sistem

\begin{tabular}{|c|c|c|c|c|c|}
\hline \multirow{2}{*}{$\begin{array}{c}\text { N } \\
\text { o }\end{array}$} & $\begin{array}{c}\text { Wak } \\
\text { tu } \\
\text { (Deti } \\
\text { k) }\end{array}$ & $\begin{array}{c}\text { Kesala } \\
\text { han }\end{array}$ & $\begin{array}{c}\text { Perhitun } \\
\text { gan } \\
\text { Manual } \\
\text { Metode } \\
\text { Fuzzy } \\
\text { Tsukamo } \\
\text { to }\end{array}$ & $\begin{array}{c}\text { Perhitun } \\
\text { gan } \\
\text { Sistem } \\
\text { Metode } \\
\text { Fuzzy } \\
\text { Tsukamo } \\
\text { to }\end{array}$ & $\begin{array}{c}\text { Keteran } \\
\text { gan } \\
\text { (T/F) }\end{array}$ \\
\hline 1 & 153 & 74 & 54.32 & 54.31 & $\mathrm{~F}$ \\
\hline 2 & 91 & 45 & 75.06 & 75.06 & $\mathrm{~T}$ \\
\hline 3 & 104 & 33 & 70.11 & 70.11 & $\mathrm{~T}$ \\
\hline 4 & 251 & 92 & 51.49 & 51.49 & $\mathrm{~T}$ \\
\hline 5 & 74 & 101 & 25 & 25 & $\mathrm{~T}$ \\
\hline
\end{tabular}

Keterangan:

$\mathrm{T}=$ True. $\quad$ Terjadi apabila hasil perhitungan sistem sama dengan perhitungan manual

$\mathrm{F}=$ False. $\quad$ Terjadi apabila hasil perhitungan sistem berbeda dengan hasil perhitungan manual

Berdasarkan pengujian validasi yang telah dilakukan, maka diperoleh:
Berdasarkan hasil pengujian menunjukkan bahwa akurasi dari perhitungan manual dan sistem menunjukan hasil yang akurat dengan akurasi sebesar $80 \%$ hal itu menunjukan bahwa sistem bekerja dengan baik.

\section{PENUTUP}

\section{A. Kesimpulan}

Kesimpulan yang dapat diambil dari hasil penelitian dan dari semua proses yang telah dilakukan dalam membangun aplikasi ini yaitu sebagai berikut:

1) Algoritma Linear Congruential Generator dapat diterapkan pada halaman kuis untuk menentukan solusi pengacakan yang tidak berganda dan pengacakan objek yang variatif berdasarkan hasil pengujian sebanyak 10 kali percobaan. Metode Fuzzy dapat diterapkan sebagai metode pemberian skor pada akhir kuis. Metode ini memiliki akurasi yang baik antara perhitungan manual dan perhitungan sistem dengan nilai akurasi sebesar $80 \%$.

2) Dalam menerapkan algoritma Linear Congruential Generator untuk pengacakan soal-soal, ada hal-hal yang harus diperhatikan. Penggunaan konstanta a (faktor penggali), $\mathrm{b}$ (penambah), $\mathrm{m}$ (modulus) dan $\mathrm{x}$ (bilangan acak) sangat menentukan pengacakan yang terjadi sehingga dengan kombinasi konstanta yang tepat maka akan dihasilkan pengacakan soal yang benar-benar acak.

\section{B. Saran}

Berdasarkan kesimpulan di atas, maka saran-saran yang diharapkan dapat digunakan pada penelitian selanjutnya yaitu sebagai berikut:

1) Pada halaman pembelajaran penulisan aksara Sunda diharapkan menggunakan algoritma untuk mencocokan input pola penulisan aksara Sunda dengan gambar. Algoritma Dynamic Time Warping dapat digunakan dalam pencocokan citra.

2) Aplikasi ini hanya dapat berjalan pada satu platform yaitu android, kelemahan ini menjadi acuhan untuk dikembangkan lebih lanjut agar aplikasi ini dapat digunakan dibeberapa platform.

3) Penentuan nilai Linear Congruential Generator konstanta a (faktor penggali), b (penambah), m (modulus) dan x (bilangan 
acak) sangat mempengaruhi baik tidak nya pembangkit bilangan acak. Sehingga hal ini menjadi sangat penting dan harus diperhatikan untuk menghasilkan bilangan yang benar-benar acak.

4) Ada banyak metode pembangkit bilangan acak yang dapat digunakan. Salah satu nya adalah metode Fisher-Yates yang dapat digunakan untuk melakukan pengacakan. Dengan mempelajari metode tersebut, diharapkan dapat mengatasi kelemahankelemahan pada metode Linear Congruential Generator dengan mempelajari metode-metode tersebut dapat mengatasi kelemahan-kelemahan pada metode Linear Congruential Generator sehingga dapat lebih memperbaiki program yang terdapat dalam tugas akhir ini.

\section{DAFTAR PUSTAKA}

[1] http://repository.widyatama.ac.id/xmlui/bitstream/h andle $/ 123456789 / 5926 /$ ab $\% 201$.pdf? sequence $=9$

diakses pada 11 Januari 2016 pukul 13:42 wib

[2] http://www.antaranews.com/berita/392249/bahasasunda-terus-tergerus diakses pada 31januari 2016 pukul 22.30

[3] http://a-

research.upi.edu/operator/upload/s_paud_0603825

_chapter2(1).pdf diakses pada 14 Januari 2016 pukul 00:52 wib

[4] http://gs.statcounter.com/\#mobile+tablet+consoleos-ID-yearly-2015-2015-bar diakses pada

31januari 2016 pukul 22.30

[5] Ginanjar Abdurrahman. 2011. Penerapan Metode Tsukamoto (Logika Fuzzy) Dalam Sistem Pendukung Keputusan Untuk Menentukan Jumlah Produksi Barang Berdasarkan Data Persediaan Dan Jumlah Permintaan. Universitas Negeri Yogyakarta. Yogyakarta.

[6] Roger S. Pressman, Ph.D. 2002. Rekayasa Perangkat Lunak. Yogyakarta: Penerbit Andi.

[7] http://sir.stikom.edu/658/7/BAB\%20III.pdf diakses pada 10 Januari 2016 pukul 15:02 wib

[8] http://eprints.uny.ac.id/8470/3/bab\%202\%2007513241018.pdf diakses pada 14 Januari 2016 pukul 07:39 wib

[9] Luky Rakhman Husen, Agus Ganda Permana, ST., MT., Suci Aulia, ST., MT. 2014. Perancangan dan Implementasi Aplikasi "Belajar Aksara Sunda" berbasis Android di Sekolah Menengah Atas Negeri 1 Tasikmalaya. Universitas Telkom. Bandung.
[10] http://unsri.ac.id/upload/arsip/ANALISIS\%20ALG ORITMA.pdf diakses pada 10 Januari 2016 pukul 15:26 wib

[11] I Made Divva Biantara, I Made Sudana, Alfa Faridh Suni, Suryono, Arimaz Hangga. 2015. Modifikasi Metode Linear Congruential Generator Untuk Optimalisasi Hasil Acak. Universitas Negeri Semarang. Semarang.

[12] T. Sutojo, S.Si., M.Kom. Edy Mulyanto, S.Si., M.Kom. Dr. Vincent Suhartono. 2011. Kecerdasan Buatan. Yogyakarta: Penerbit Andi.

[13] Nazruddin Safaat H. 2006. Pemrograman Aplikasi Mobile Smartphone Dan Tablet PC Berbasis Android. Bandung: Penerbit Informatika.

[14] Martin Fowler. 2003. UML Distilled Edisi 3. Yogyakarta: Penerbit Andi. 